\title{
Commemorating Mércèdes Pavlicevic
}

\author{
Kobie Temmingh Swart ${ }^{1 *}$, Sunelle Fouché ${ }^{2}$ \\ 1 University of Pretoria, South Africa, \\ 2 MusicWorks, South Africa \\ *kobie.swart@hotmail.com
}

Published: 1 July 2018

\begin{abstract}
Without an African Voice, music therapy worldwide risks remaining a practice created by the vast written tracts that have become part of the international music therapy canon. The canon that music therapy students everywhere study, absorb, believe in - and what music therapy is NOT, then, is loudly stated by what the canon omits. Even if music therapy in Africa does not speak 'in the global tongue', it needs to be sounded, voiced, noted, and heard. Or remain invisible, non-existent, an illusion. (Pavlicevic, 2004)
\end{abstract}

Anybody who has known Mércèdes continues to admire and respect her impressive, seemingly boundless intellect, her ability to think critically, her inquisitiveness, uncanny insight, sparkling energy, passion, drive, commitment, creativity, and not least of all, her wonderful sense of humor that could enliven and transform the dreariest of moments.

She brought all of this to South Africa, leaving a rich, vibrant legacy for our burgeoning profession. Without Mércèdes, the development of music therapy in the country would certainly not have been what it is today, or might not have existed. In 1999 Mércèdes founded the Master's Degree Program in Music Therapy at the University of Pretoria with a colleague, Kobie Temmingh Swart. Entering the mental health scene, where almost no one knew anything about music therapy was daunting, but Mércèdes was determined and used all of her copius resources to make it happen.

Mércèdes' considerable skills and knowledge as researcher, lecturer, clinician, and writer were invaluable, firmly supporting the development of a high caliber training program. Her theoretical contributions in the field of music therapy have been extensive, and as researcher, she initiated, led, and supervised many South African research projects. As a clinician, she contributed richly to the skill development of her students and colleagues and to the lives of many individuals and groups in various communities. Mércèdes spent eight years in full capacity at the university, after which she gave the reigns to Carol Lotter, but continued to lecture and examine on a part-time basis until 2016.

Mércèdes has walked alongside MusicWorks since its inception in 2002. MusicWorks, previously known as the Music Therapy Community Clinic, offers music interventions in marginalized Capetonian neighborhoods. Mércèdes mentored and encouraged the founders, Sunelle Fouché and Kerryn Torrance, through the then unknown territory of community music therapy. Throughout the years, right up to a few days before her passing, she continued to be a mentor to those at MusicWorks, helping them to understand the kind of music therapists they needed to be within the communities they served, offering deeper meaning when needed, and stimulating more creative, innovative, and context-sensitive practice. Towards the end of 2018 MusicWorks would have served 5000 children since its inception. 
As the South African music therapy community, we are forever grateful for the abundance that was and will continue to be Mércèdes! We will continue to plough what we received from Mércèdes back into our country and its people, so that music therapy in South Africa may continue to be increasingly "sounded, voiced, noted and heard."

We feel the loss of Mércèdes in our bones, and our love and deepest sympathy go to her partner, family, friends, and all her colleagues.

\section{References}

Pavlicevic, M. (2004). Calling African voices. Voices Resources. Retrieved from

http://testvoices.uib.no/community/?q=fortnightly-columns/2004-calling-african-voices 